Pacific Journal of Mathematics

ON THE OTHER SET OF THE BIORTHOGONAI
POLYNOMIALS SUGGESTED BY THE LAGUERPE

tilak Raj Prabhakar 


\title{
ON THE OTHER SET OF THE BIORTHOGONAL POLYNOMIALS SUGGESTED BY THE LAGUERRE POLYNOMIALS
}

\author{
TILAK RAJ PRABHAKAR
}

Recently Konhauser considered the biorthogonal pair of polynomial sets $\left\{Z_{n}^{\alpha}(x ; k)\right\}$ and $\left\{Y_{n}^{\alpha}(x ; k)\right\}$ over $(0, \infty)$ with respect to the weight function $x^{\alpha} e^{-x}$ and the basic polynomials $x^{k}$ and $x$. For the polynomials $Y_{n}^{\alpha}(x ; k)$, a generating function, some integral representations, two finite sum formulae, an infinite series and a generalized Rodrigues formula are obtained in this paper.

Biorthogonality and some other properties of $Z_{n}^{\alpha}(x ; k)$ and $Y_{n}^{\alpha}(x ; k)$ for any positive integer $k$ were discussed by Konhauser ([1], [2]). For $k=2$, the polynomials were discussed earlier by Preiser [4]. For $k=1$, the polynomials $Y_{n}^{\alpha}(x ; k)$, as also $Z_{n}^{\alpha}(x ; k)$, reduce to the generalized Laguerre polynomials $L_{n}^{\alpha}(x)$.

In a recent paper [3], we obtained generating functions and other results for the polynomials $Z_{n}^{\alpha}(x ; k)$ in $x^{k}$. The present paper is concerned only with the polynomials $Y_{n}^{\alpha}(x ; k)$ in $x$ which form the other set of the biorthogonal pair. The results of the paper reduce, when $k=1$, to some standard properties of $L_{n}^{\alpha}(x)$. Simplicity of the procedure for deriving the generating relation (2.1) which may be regarded as our principal result, seems to be of some passing interest.

2. A generating function for $Y_{n}^{\alpha}(x ; k)$. We begin with the contour integral representation [2, (26)]

$$
Y_{n}^{\alpha}(x ; k)=(k / 2 \pi i) \int_{C} e^{-x t}(t+1)^{\alpha+k n}\left[(t+1)^{k}-1\right]^{-(n+1)} d t
$$

where we take $C$ as a closed contour enclosing $t=0$ and lying within $|t|<1$. If we make the substitution $u=1-(t+1)^{-k}$, we get another integral representation for $Y_{n}^{\alpha}(x ; k)$, viz.

$$
Y_{n}^{\alpha}(x ; k)=(2 \pi i)^{-1} \int_{C^{\prime}}(1-u)^{-(\alpha+1) / k} \exp \left[x\left\{1-(1-u)^{-1 / k}\right\}\right] u^{-n-1} d u
$$

$C^{\prime}$ being a circle with centre $u=0$ and a small radius. By standard arguments of complex analysis we obtain the generating relation

$$
\sum_{n=0}^{\infty} Y_{n}^{\alpha}(x ; k) u^{n}=(1-u)^{-(\alpha+1) / k} \exp \left[x\left\{1-(1-u)^{-1 / k}\right\}\right]
$$

for $\operatorname{Re}(\alpha+1)>0,|u|<1$ and positive integers $k$. 
Since the generating relation (2.3) is of the form

$$
A(u) \exp [x H(u)]=\sum_{n=0}^{\infty} Y_{n}^{\alpha}(x ; k) u^{n},
$$

it at once follows ([6], [5]) that the set $\left\{Y_{n}^{\alpha}(x ; k)\right\}$ is of Sheffer $A$-type zero. One of the several immediate consequences of this fact [5, Theorems 73-76] is that there exists a sequence $\left\{h_{i}\right\}$ independent of $x$ and $n$ such that

$$
D Y_{n}^{\alpha}(x ; k)=\sum_{m=0}^{n-1} h_{m} Y_{n-m-1}^{\alpha}(x ; k) .
$$

In (2.2) putting $s=x^{k}(1-u)^{-1}$, we are led to still another integral representation

$$
Y_{n}^{\alpha}(x ; k)=(2 \pi i)^{-1} e^{x} x^{k-\alpha-1} \int_{\sigma} s^{n-1+(\alpha+1) / k} \exp \left(-s^{1 / k}\right)\left(s-x^{k}\right)^{-n-1} d s
$$

where $\sigma$ denotes the circle $\left|s-x^{k}\right|=r$ with small $r$. Evidently $\sigma$ may be any small closed contour encircling $s=x^{k}$.

Evaluating the integral in (2.5) by the residue theorem, we obtain a generalized Rodrigues formula:

$$
Y_{n}^{\alpha}(x ; k)=(n !)^{-1} e^{x} x^{k-\alpha-1}\left[D^{n} s^{n-1+(\alpha+1) / k} \exp \left(-s^{1 / k}\right)\right]_{s=x^{k}} .
$$

For $k=1$, it reduces to the Rodrigues formula for $L_{n}^{\alpha}(x)$.

3. Applications. In this section we apply the generating relation of the previous section to obtain two finite sum formulae for $Y_{n}^{\alpha}(x ; k)$ and also to prove a result involving an infinite series of these polynomials.

a. Two finite sums involving $Y_{n}^{\alpha}(x ; k)$. From the generating relation (2.3) and the simple relation

$$
(1-u)^{-(\alpha+1) / k}=(1-u)^{-(\beta+1) / k} \sum_{m=0}^{\infty}(m !)^{-1}\left(\frac{\alpha-\beta}{k}\right)_{m} u^{m},
$$

if follows that

$$
Y_{n}^{\alpha}(x ; k)=\sum_{m=0}^{n}(m !)^{-1}\left(\frac{\alpha-\beta}{k}\right)_{m} Y_{n-m}^{\beta}(x ; k)
$$

where $\alpha$ and $\beta$ are arbitrary.

Also from (2.3), on using

$$
\begin{aligned}
(1-u)^{-\{(\alpha+\beta+1)+1 j / k} \exp \left[(x+y)\left\{1-(1-u)^{-1 / k}\right\}\right] \\
=(1-u)^{-(\alpha+1) / k} \exp \left[x\left\{1-(1-u)^{-1 / k}\right\}\right] \cdot(1-u)^{-(\beta+1) / k} \\
\quad \times \exp \left[y\left\{1-(1-u)^{-1 / k}\right\}\right]
\end{aligned}
$$

we get that 


$$
Y_{n}^{\alpha+\beta+1}(x+y ; k)=\sum_{m=0}^{n} Y_{m}^{\alpha}(x ; k) Y_{n-m}^{\beta}(y ; k)
$$

for arbitrary $\alpha$ and $\beta$.

b. A series of polynomials $Y_{n}^{\alpha}(x ; k)$. We show that

$$
\begin{aligned}
& \sum_{n=0}^{\infty} \frac{(n+m) !}{n ! m !} Y_{n+m}^{\alpha}(x ; k) u^{n} \\
& \quad=(1-u)^{-(\alpha+m k+1) / k} \exp \left[x\left\{1-(1-u)^{-1 / k}\right\}\right] Y_{m}^{\alpha}\left(x(1-u)^{-1 / k} ; k\right) .
\end{aligned}
$$

Using the obvious result

$$
1-u-v=(1-u)\left\{1-v(1-u)^{-1}\right\}
$$

we have that

$$
\begin{aligned}
F(u, v) \equiv & (1-u-v)^{-(\alpha+1) / k} \exp \left[x\left\{1-(1-u-v)^{-1 / k}\right\}\right] \\
= & (1-u)^{-(\alpha+1) / k} \exp \left[x\left\{1-(1-u)^{-1 / k}\right\}\right] \cdot\left(1-v(1-u)^{-1}\right)^{-(\alpha+1) / k} \\
& \cdot \exp \left[x(1-u)^{-1 / k}\left\{1-\left(1-v(1-u)^{-1}\right)^{-1 / k}\right\}\right] \\
= & (1-u)^{-(\alpha+1) / k} \exp \left[x\left\{1-(1-u)^{-1 / k}\right\}\right] \\
& \cdot \sum_{m=0}^{\infty} Y_{m}^{\alpha}\left(x(1-u)^{-1 / k} ; k\right)\left[v(1-u)^{-1}\right]^{m},
\end{aligned}
$$

applying (2.3). But using (2.3), we also find that

$$
\begin{aligned}
F(u, v) & =\sum_{n=0}^{\infty} Y_{n}^{\alpha}(x ; k)(u+v)^{n} \\
& =\sum_{n=0}^{\infty} \sum_{m=0}^{n} \frac{n !}{m !(n-m) !} u^{n-m} v^{m} Y_{n}^{\alpha}(x ; k) \\
& =\sum_{m=0}^{\infty} \sum_{n=0}^{\infty} \frac{(m+n) !}{m ! n !} Y_{n+m}^{\alpha}(x ; k) u^{n} v^{m} .
\end{aligned}
$$

Comparing the coefficients of $v^{m}$ in the two expansions obtained for $F(u, v)$, we obtain (3.3).

This result is analogous to a property possessed by almost all the classical orthogonal polynomials [5; 95(7), 111(1), 120(9), 144(23)] except possibly by the Jacobi polynomials.

\section{REFERENCES}

1. J. D. E. Konhauser, Some properties of biorthogonal polynomials, J. Math. Anal. Appl., 11 (1965), 242-260.

2. - Biorthogonal polynomials suggested by the Laguerre polynomials, Pacific

J. Math., 21 (1967), 303-314.

3. Tilak Raj Prabhakar, On a set of polynomials suggested by Laguerre polynomials, Pacific J. Math., 35 (1970), 213-219. 
4. S. Preiser, An investigation of biorthogonal polynomials derivable from ordinary differential equations of the third order, J. Math. Anal. Appl., 4 (1962), 38-64.

5. E. D. Rainville, Special Functions, Macmillan, New York, 1960.

6. I. M. Sheffer, Some properties of polynomial sets of type zero, Duke Math. J., 5 (1939), 590-622.

Received June 29, 1970.

Ramjas College

UnIVERSITy OF DELhI 


\title{
PACIFIC JOURNAL OF MATHEMATICS
}

\author{
EDITORS
}

\author{
H. SAMelson \\ Stanford University \\ Stanford, California 94305 \\ C. R. HoBBy \\ University of Washington \\ Seattle, Washington 98105
}

J. DugunduI

Department of Mathematics

University of Southern California

Los Angeles, California 90007

RICHARD ARENS

University of California

Los Angeles, California 90024

\section{ASSOCIATE EDITORS}

\author{
E. F. BeCKENBACH
}

B. H. NEUMANN

F. WoLF

K. YOSHIDA

\section{SUPPORTING INSTITUTIONS}

\author{
UNIVERSITY OF BRITISH COLUMBIA \\ CALIFORNIA INSTITUTE OF TECHNOLOGY \\ UNIVERSITY OF CALIFORNIA \\ MONTANA STATE UNIVERSITY \\ UNIVERSITY OF NEVADA \\ NEW MEXICO STATE UNIVERSITY \\ OREGON STATE UNIVERSITY \\ UNIVERSITY OF OREGON \\ OSAKA UNIVERSITY \\ UNIVERSITY OF SOUTHERN CALIFORNIA
}

\author{
STANFORD UNIVERSITY \\ UNIVERSITY OF TOKYO \\ UNIVERSITY OF UTAH \\ WASHINGTON STATE UNIVERSITY \\ UNIVERSITY OF WASHINGTON \\ AMERICAN MATHEMATICAL SOCIETY \\ CHEVRON RESEARCH CORPORATION \\ NAVAL WEAPONS CENTER
}

The Supporting Institutions listed above contribute to the cost of publication of this Journal, but they are not owners or publishers and have no responsibility for its content or policies.

Mathematical papers intended for publication in the Pacific Journal of Mathematics should be in typed form or offset-reproduced, (not dittoed), double spaced with large margins. Underline Greek letters in red, German in green, and script in blue. The first paragraph or two must be capable of being used separately as a synopsis of the entire paper. The editorial "we" must not be used in the synopsis, and items of the bibliography should not be cited there unless absolutely necessary, in which case they must be identified by author and Journal, rather than by item number. Manuscripts, in duplicate if possible, may be sent to any one of the four editors. Please classify according to the scheme of Math. Rev. Index to Vol. 39. All other communications to the editors should be addressed to the managing editor, Richard Arens, University of California, Los Angeles, California, 90024.

50 reprints are provided free for each article; additional copies may be obtained at cost in multiples of 50 .

The Pacific Journal of Mathematics is published monthly. Effective with Volume 16 the price per volume (3 numbers) is $\$ 8.00$; single issues, $\$ 3.00$. Special price for current issues to individual faculty members of supporting institutions and to individual members of the American Mathematical Society: $\$ 4.00$ per volume; single issues $\$ 1.50$. Back numbers are available.

Subscriptions, orders for back numbers, and changes of address should be sent to Pacific Journal of Mathematics, 103 Highland Boulevard, Berkeley, California, 94708.

PUBLISHED BY PACIFIC JOURNAL OF MATHEMATICS, A NON-PROFIT CORPORATION

Printed at Kokusai Bunken Insatsusha (International Academic Printing Co., Ltd.), 7-17, Fujimi 2-chome, Chiyoda-ku, Tokyo, Japan. 


\section{Pacific Journal of Mathematics}

\section{Vol. 37, No. $3 \quad$ March, 1971}

Mohammad Shafqat Ali and Marvin David Marcus, On the degree of the

minimal polynomial of a commutator operator ................ 561

Howard Anton and William J. Pervin, Integration on topological

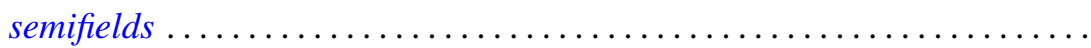

Martin Bartelt, Multipliers and operator algebras on bounded analytic

functions .................................... 575

Donald Earl Bennett, Aposyndetic properties of unicoherent continua ...... 585

James W. Bond, Lie algebras of genus one and genus two ............. 591

Mario Borelli, The cohomology of divisorial varieties ............... 617

Carlos R. Borges, How to recognize homeomorphisms and isometries ....... 625

J. C. Breckenridge, Burkill-Cesari integrals of quasi additive interval

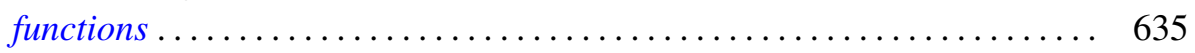

J. Csima, A class of counterexamples on permanents ................ 655

Carl Hanson Fitzgerald, Conformal mappings onto $\omega$-swirly domains . . . . . . 657

Newcomb Greenleaf, Analytic sheaves on Klein surfaces .............. 671

G. Goss and Giovanni Viglino, C-compact and functionally compact

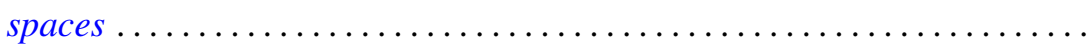

Charles Lemuel Hagopian, Arcwise connectivity of semi-aposyndetic plane

continua ..................................... 683

John Harris and Olga Higgins, Prime generators with parabolic limits ...

David Michael Henry, Stratifiable spaces, semi-stratifiable spaces, and their

relation through mappings .......................

Raymond D. Holmes, On contractive semigroups of mappings ........... 701

Joseph Edmund Kist and P. H. Maserick, BV-functions on semilattices ....... 711

Shûichirô Maeda, On point-free parallelism and Wilcox lattices ........... 725

Gary L. Musser, Linear semiprime $(p ; q)$ radicals ................. 749

William Charles Nemitz and Thomas Paul Whaley, Varieties of implicative

semilattices..................................... 759

Jaroslav Nešetřil, A congruence theorem for asymmetric trees ............ 771

Robert Anthony Nowlan, A study of $H$-spaces via left translations .......... 779

Gert Kjærgaard Pedersen, Atomic and diffuse functionals on a $C^{*}$-algebra ... 795

Tilak Raj Prabhakar, On the other set of the biorthogonal polynomials

suggested by the Laguerre polynomials...

801

Leland Edward Rogers, Mutually aposyndetic products of chainable

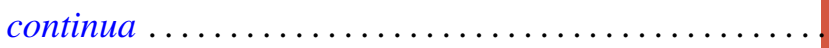

Frederick Stern, An estimate for Wiener integrals connected with squared

error in a Fourier series approximation.

Leonard Paul Sternbach, On k-shrinking and k-boundedly complete basic

sequences and quasi-reflexive spaces .................... 817

Pak-Ken Wong, Modular annihilator $A^{*}$-algebras ........ 